\title{
探秘香港西区公众货物装卸区 UNFOLDING THE WESTERN DISTRICT PUBLIC CARGO WORKING AREA IN HONG KONG
}

庞宇灵景观设计师, 哈佛大学设计研究生院设计学硕士

Benni Yu-ling PONG Landscape Architect; Master in Design Studies,

Graduate School of Design, Harvard University

Tuen Mun, Hong Kong

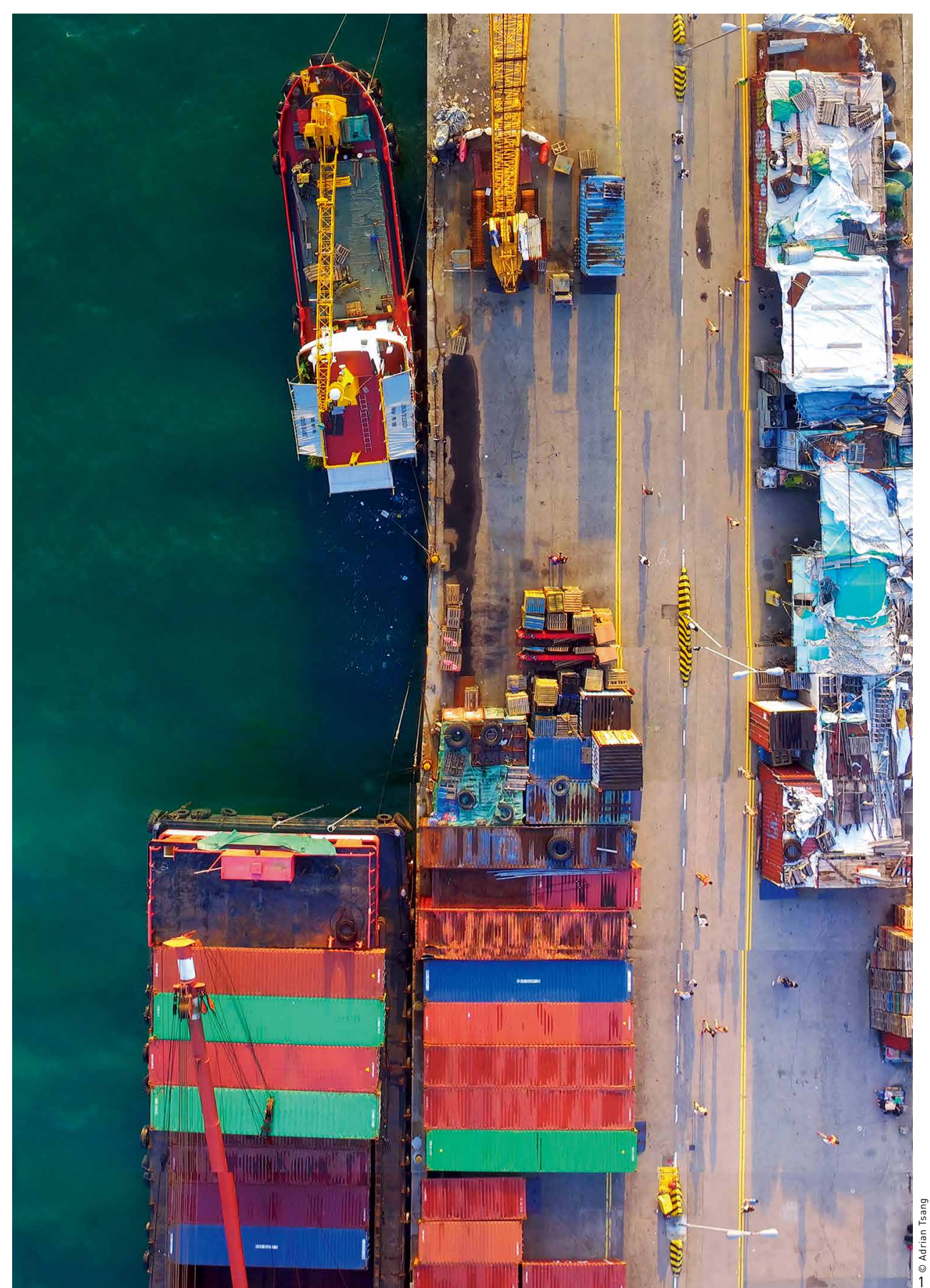




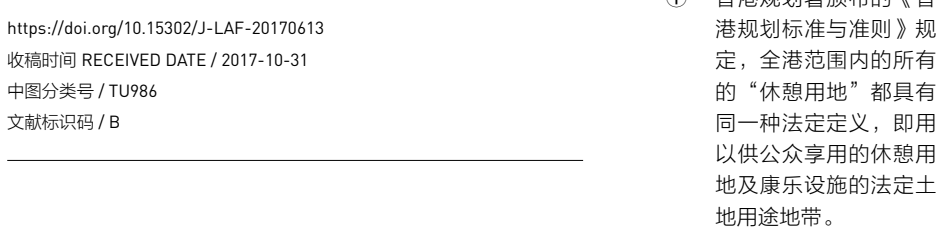
港规划标准与准则》规 定, 全港范围内的所有 , 全港范围内的所有 “休覟用地” 都具有 以供公众享用的休㮩用 以供公众享用的休蒩用 地用途地带。 计” 和 “非规划”的空间。这个被公众占用的空间不但吸引 了本地和海外媒体的关注, 更深受人们喜爱。相较于主流规 划和设计实践对城市空间的演绎, 这种活泼的空间展示了人 们对城市空间别样的理解和美学价值观。

本项目旨在通过人类学研究方法和视觉再现手法, 纪录 和定义在WDPCWA发生的现象, 并探究人们对城市空间的 感知。针对设计实践过程极易忽视人们对空间的抽象感知这 一现象, 本项目尝试发掘一套方法论, 以展示这些难以被量 化的讯息。

公共空间; 非设计空间; 设计人类学; 再现; 香港

\section{ABSTRACT}

The Western District Public Cargo Working Area (WDPCWA) in Hong Kong is an appropriated public space that is "undesigned" and "unplanned" in nature. Yet, it is one of the most popular public spaces among the local residents and has received the extensive coverage by both local and overseas media. The vibrant space has represented a different undestanding and with space hrection incorporappreciation on the quality of urben space that is not incorporated in the mainstream design and planning practice and pedagogy.

This project aims to record and conceptualize the urban phenomenon happened in the WDPCWA and scrutinize human perception on space through ethnographic methodology and visual representation. It intends to explore a methodology to unveil the perceptually-defined qualitative aspects in urban space which are often overlooked in design practice. Space which are

Public Space; Undesigned Space; Design Anthropology; Representation; Hong Kong

译 孙一鹤 陆小璇

TRANSLATED BY Robin SUN Xiaoxuan LU
人们对于世界的微观知觉或典型体验 来自于散布在各个方向上的小褶皱，它们相 互融合、叠加、相接……这些时而微小、时 而模糊、时而混杂的认知相互积聚, 构成了 我们的宏观知觉一一有意识的、清晰而明确 的统觉。”

一吉尔・ 德勒兹, $1993^{[1]}$

\section{非设计空间}

尽管从未被规划或设计为一个正式 的休䕀用地 ${ }^{1}$ ，香港西区公众货物装卸区 (WDPCWA) 却成为了备受人们喜爱的公 共空间。因其浓厚的自由氛围与高度的适应 性, WDPCWA赢得了2013年度香港公共 空间大奖的青睐。尽管从严格意义上讲，该 区域并不允许非物流活动的开展，但这里因 拥有可极目远眺滨海景观的宏大视野而受到 了媒体的广泛关注, 吸引着众人陆续到来。

在市域地图中, 该地区呈现为一个平 坦而空旷的形态，区域内多种多样的人类活 动, 以及其政治、经济、社会和环境关系混 杂交错的特征并未得到展现。在WDPCWA 中自发形成的活动却生机勃勃, 而这在传统 城市规划及设计的实践项目和教科书中都甚 少出现。侧重于形式具体、含义明确、定量 分析、几何形制与地形地势的传统设计方法 无法表达这些未经设计的活动以及其中不可 触知、漫无边界且持续变化的感知过程。

事实上, 公众使用WDPCWA的方式 是极具策略性的, 他们会钻法律上的漏洞, 把握一切空间和时间机会对这些空间加以利 用, 并迂回占有。这类空间代表着一种另类 的审美观念, 一种对城市空间的别样感知, 以及一种对都市主义的独特解读。本项目旨 在定义和阐释隐藏于空间之中的褶皱—在 设计实践中极易被忽视和弱化的细节之处; 同时探究感知层面非设计空间的美学价值。

\section{设计人类学}

人类学对于空间的研究兴趣往往与城市 规划专家的关注点相契合。不同于在设计过
程中较少进行全面实地观察的机械化的场地 分析, 该项目结合了民族志研究方法和视觉 再现手法, 认为如果设计师针对空间和社区 进行了足够长时间的深入调查, 将做出不同 的设计实践。

对于民族志学者而言, 保证观察的客观 性是重中之重, 尤其当调查对象为社会边缘 人群时, 他们更是需要将这一点牢记于心。 在项目初期的研究中, 并不涉及这类问题。 参与式观察远比研究基于方法论的文献更为 有趣一一简单而随机的交谈会带来人际交往 中的意外惊喜。其中, 在码头上与他人闲坐 聊天是最有收获的观察策略。

\section{占用空间与天空之镜}

WDPCWA位于香港西区, 俗称西环码 头或 “照片墙” 码头。这一经由填海造地形 成的码头现被规划为公共货运区域。自建成 以来, 当地居民圈地和私占现象偶有发生。 直到被推选为最受欢迎的公共空间, 并且有 无数照片被分享到 “照片墙” 软件上之后, 这个空间才渐为人知, 并登上了《时代》杂 志和《国家地理》杂志。虽然拥有“香港天 空之镜” 这一浪漫昵称, 但这处空间实则 是一片位于主码头末端的末经维护的裸露地 表。每逢雨后, 这处凹陷的地块上都会形成 一层薄薄的广阔水面, 完美地反射出维多利 亚港的全景和迷人的日落。

当地居民将WDPCWA视为社区生活 的一部分, 很多居民坚持认为他们眼中的码 头与“外人”所看到的并不一样, 还有一些 人坚信他们有 “权力” 和 “义务” 为这里 制定道德规范和秩序规则, 且至少形成约定 俗成的约束力。而对于外来者而言, 到访 WDPCWA并非其生活的一部分, 他们只 是想前来寻找 “隐秘的天堂” ，越是警告他 们, 便越会激发他们到访的欲望。还有一些 边缘使用者, 他们的活动十分隐蔽, 几乎无 从察觉。

不同的使用者对于空间的使用偏好大相 径庭。且不论感知角度的差异, WDPCWA 这处未经规划的 “毛坏” 平台的确最大限度 
地激发了多样的人类活动，提供了无尽的想 象空间。

\section{心照不宣的协定}

码头上生机勃勃的活动常常造成这处空 间混乱无序的假象。事实上, WDPCWA设 置了很多规则。海事处的警告标识被明确张 贴在入口处，货运商也会在其泊位区内张贴 印有俚语的非正式警告标识。虽然在运营时 间进入场地、面对刺着纹身的半裸男工带有 “攻击性” 的眼神并不是什么愉快的经历, 但这也正是争议所在一一因为在非运营时 间, WDPCWA是一个㩊家集会的空间。

只要不是出格的行为, 货运商对公众 使用通常保持包容的态度。由于政府计划将 该地块由物流功能用地转变为滨海步行道, 货运商意识到接纳公众使用其实对他们更为 有利，所以他们也曾呼呼一项能够兼顾民众 享用和物流功能的双赢提案。公众使用者很 清楚一旦他们的活动引起了海事处或货运商 的注意, 就很有可能被禁止继续使用这处空 间。显然，他们巧妙地抓住了一切空间和时 间的空隙机会，在不干扰物流运营的前提下 到访场地。虽然投诉事件只是偶有发生，但
海事处仍强调, 出于安全因素考虑, 必须禁 止公众入内。警卫有时也会向公众出示警 告, 劝诫他们离开, 但这些举措收效甚微。 究其原因, 一方面警卫的态度让人完全感受 不到紧迫感，另一方面人们也不相信会受到 处罚。

使用者、政府及货运商之间的关系建 立在 “规避麻烦” 的心态之上。这种心照不 宣的协定意味着 “只要没有大麻烦, 一切照 旧。”使用者间的活动存在一种相互制约的 关系，没有书面规定并不意味着没有秩序， 正是这种陌生人之间基于社会规范的潜规则 在约束着人们的行为。

\section{象征：过去和未来}

在调查过程中, 很多受访者能够准确讲 述出该地区的历史和已拆除地标的位置。这 个 “无拘无束的”码头是许多居民心中 “追 忆昔日美好时光”的象征。除了对过去的怀 缅, WDPCWA也能够带给人们对未来的 憧憬：绿色和平组织以该码头为背景来宣传 他们的运动; 甚至庆祝香港特别行政区成立 20 周年的政府宣传片也在此拍摄。当屏幕上 出现展示WDPCWA的场景时，字幕写道:

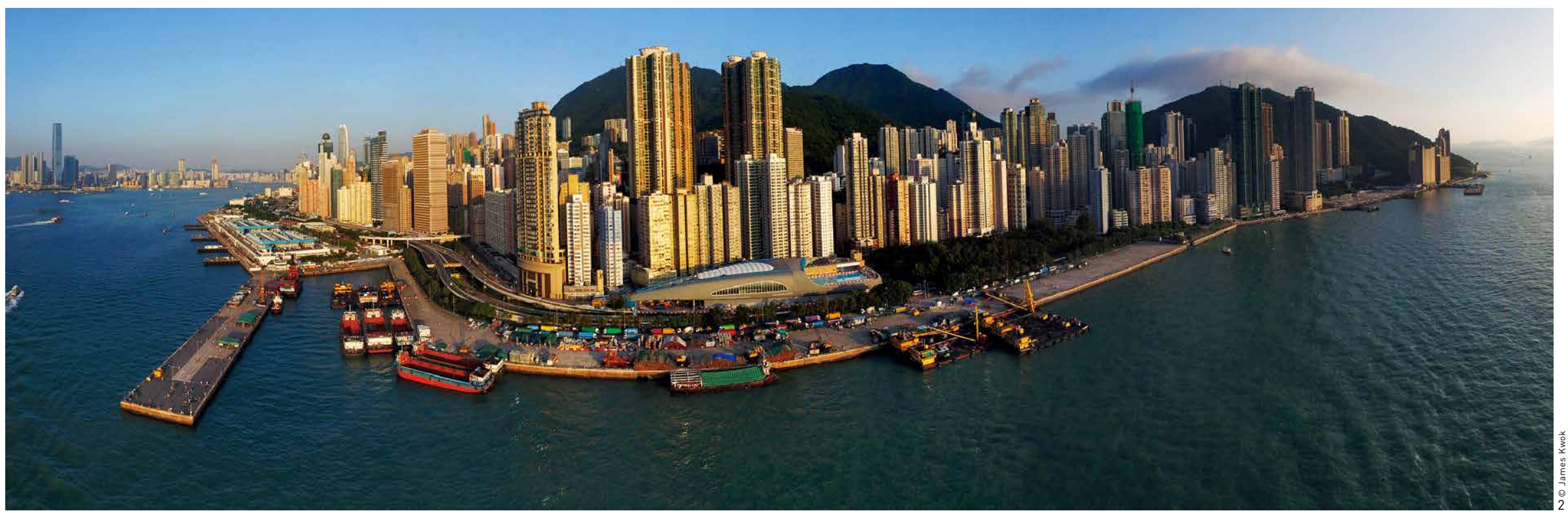




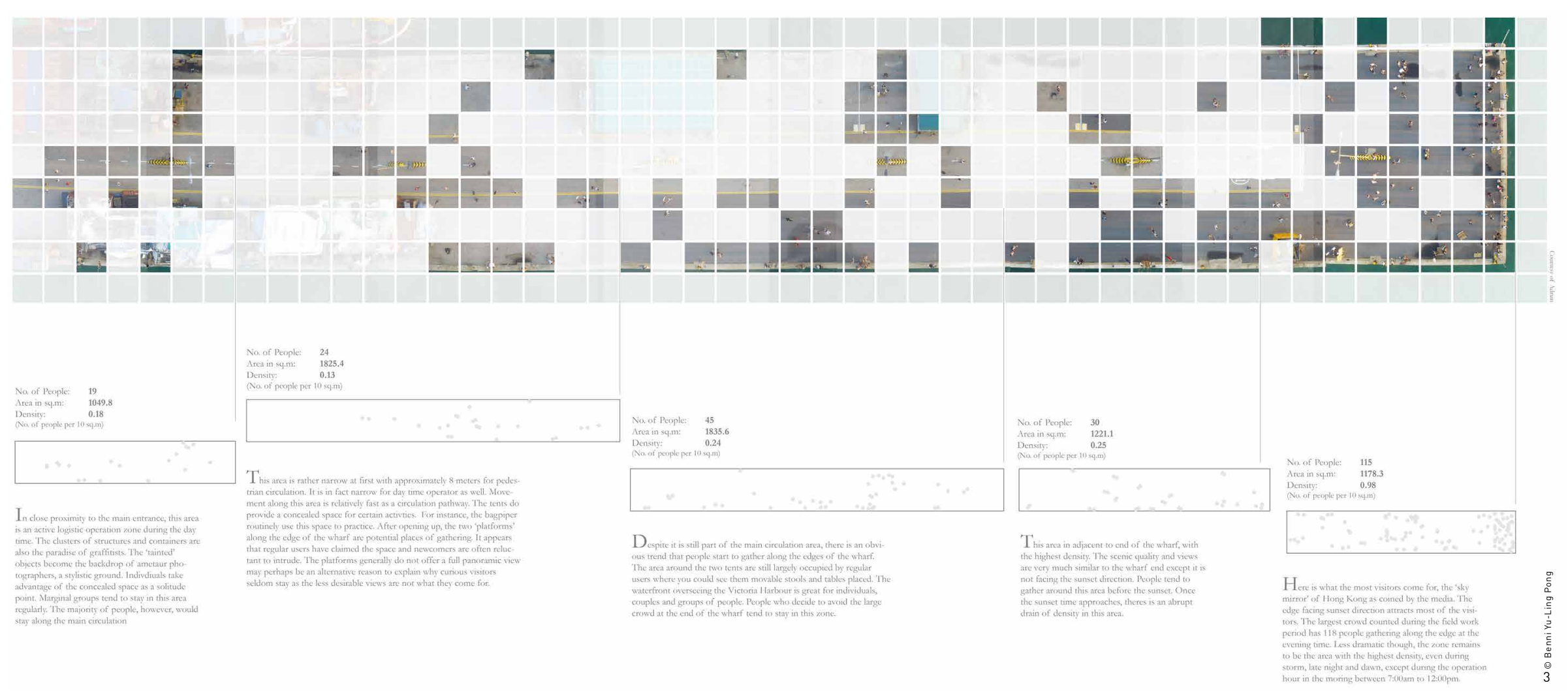

“这里有我们的未来和希望”。尽管码头的 前途未明, 但WDPCWA的开放环境似乎遮 盖了其未来不确定性的阴影。很多受访者描 绘出他们心中理想的香港, 并认为这里是 证明非常规发展模式可能性的鲜活范例。

但WDPCWA注定只能是短暂存在的。 在某机构推出的设计方案中, 码头现状被描 述为 “杂乱而沉闷”。该方案对目前场地上 正在进行的人类活动熟视无睹, 转而建议将 场地 “打造为香港海港的西大门”。虽然这 并不完全是自上而下的规划, 它基于当地非 政府组织的一项倡议, 且参考了邻近街区其 他自下而上的规划模式。但无论是何种规划 模式，码头的现有使用者对于WDPCWA的 未来发展都影响甚微, 一方面他们不愿参与 到正式的规划过程中, 另一方面新规划的预 期 “收益”也将远高于维持现状。

\section{另类美学}

不是每个人都能欣赏WDPCWA之 美。很多人可能更偏爱那些经过设计的公 园。有些人将码头视为 “危险” 的地方, 因 而局限了空间的 “无尽利用可能”，也使 WDPCWA未能被纳入到 “公园” 的范畴之 中。走进这个隐秘空间就仿佛在漫无目的地 游荡，在一场安全的冒险中去发现城市不同 寻常的一面。在这里, 人们可以稍稍放纵, 打破禁忌，童年的记忆和开怀嬉戏的感觉被 一一唤醒。

伊戈纳西·德·索拉 - 莫拉埃尔 ·卢比 奥使用“模糊地块” 这一术语来描绘后工业 时期废弃的城市景观 ${ }^{[2]}$ 。在模糊地块的定义 中, “模糊” 既指 “空旷的、闲置的” , 也 指 “不受管理的、可用的、无约束的”，这
正好契合了WDPCWA的特性。克里斯托 夫 - 吉鲁特认为, 模糊地块是 20 世纪物质空 间的普遍现象, 其 “与有意识的景观设计完 全对立” [3]。

如何将这种不寻常的美学观念融入到我 们的设计实践中? 这是一个有趣的问题。

\section{非设计空间中的设计师}

设计是一个系统性的过程。它保证了无 数量化数据的供给, 并旨在反映主流设计和 规划准则所关注的内在关系。但这些数据并 不能衡量美学价值、个人经验、感知以及人 们在WDPCWA中被赋予的自由感。当设 计方法忽略掉这些难以被量化的信息, 得到 的设计结果总是相似的。设计师总渴望做出 更丰富的设计, 设计空白的空间是需要勇气 
3. 人群行为分析。通过 将场地分成一个个 $4.5 \mathrm{~m} \times 4.5 \mathrm{~m}$ 的格子, 并 对典型活动的空问分布 和人群密度进行分析, 和群密度进行分析, 可以探究人们在这块几 乎没有规划任何活动的 空地上的行为模式

4. WDPCWA活动空间分析

3. Crowd behaviour analysis. By studying the spatiality and density of the site in a $4.5 \mathrm{~m} \times 4.5 \mathrm{~m}$ grid capturing the time of the pick activities, it aims to explore how human behave in a plain surface with minima programming. programming. Spatial distribution WDPCWA
的。不仅委托方要求更高的经济收益，设计 师也要追求量化指标和外观设计。这使得设 计师常常纠结于成为完美主义者还是实用主 义者, 却忽略了使用者的真正需求。

我和许多同仁都讨论过WDPCWA。 他们中的大多数人都被这个空间所吸引，而 他们的评判和观点都聚焦到了同一个重点 上一一设计师能够从这处空间中学到什么? 很多人期望从对码头的调查中总结出 “万用 定律”，并定制出能够创造“成功”空间的 设计模式。另一方面, 倡议团体则经常指责 设计师破坏了公共空间, 把所有问题都归 各于设计, 这种想法与认为好的设计就能 解决所有问题同样天真。公共空间的鬼龹力之
处恰巧在于其不可预测性、互动性及其中复 杂的关系。

人类学是将设计实践与难以被量化的 人类生活与感知联系起来的潜在方法论。设 计不能仅仅满足于 “知道怎么做”，还必须 “知道为什么”。如果说是设计催化了社会 的变革, 设计师就必须意识到设计将改变什 么。这个项目最初的目标是解决设计过程中 的一些问题, 而最终开启了更多对主流设计方 式的质疑。当人们询问我对码头未来有何展望 时, 我无法作答。我认为, 我的研究仅仅标志 着一个持续过程的开端, 我并非想要立刻思考 出一种可行的解决方案, 而是旨在探索设计与 人类感知和社区群体之间的相互作用。LAF

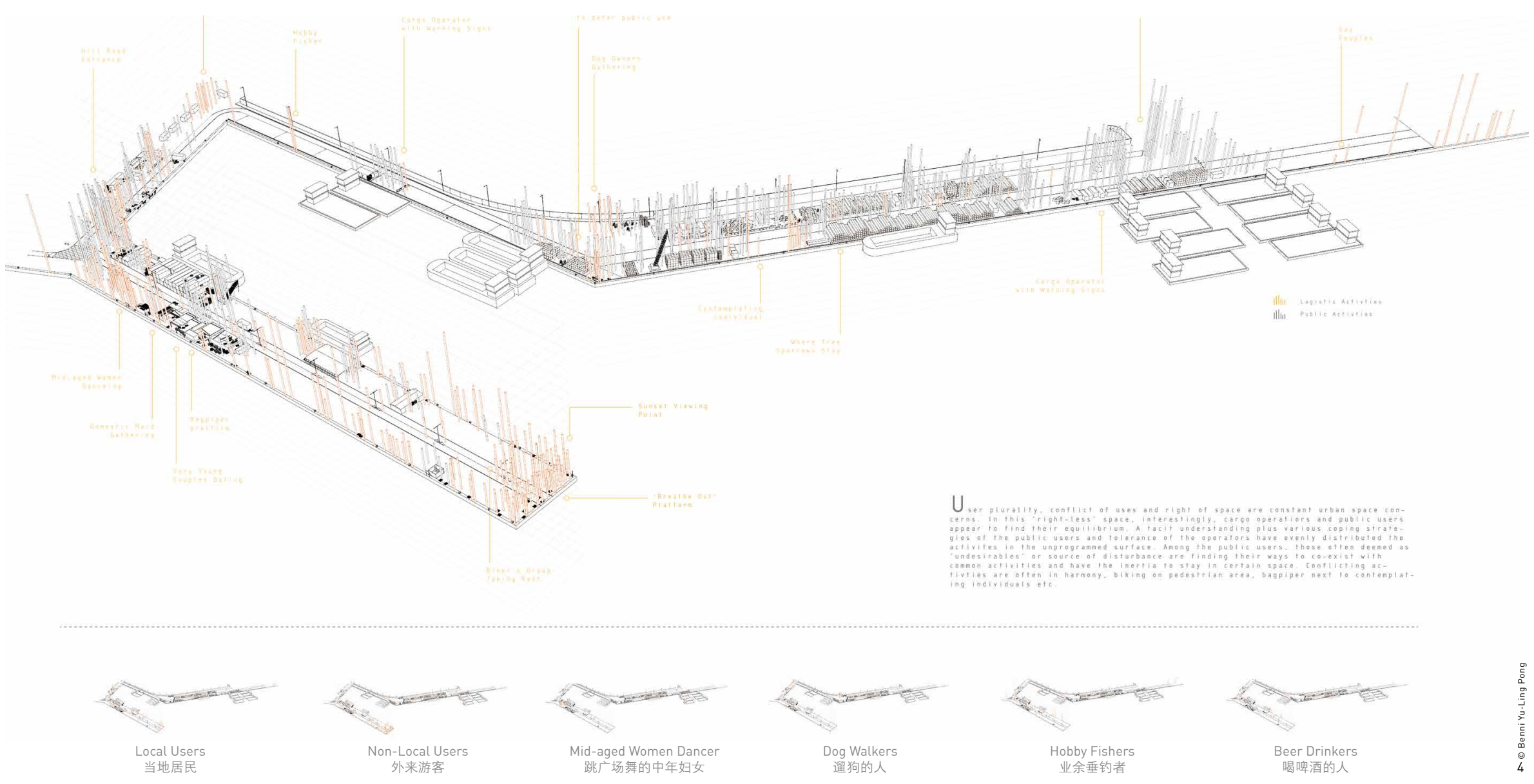


"Micro-perceptions or representatives of the world are these little folds that unravel in every direction, folds in folds, over folds, following folds.... And these are minute, obscure, confusing perceptions that make up our macro-perceptions, our conscious, clear and distinct apperceptions."

— Gilles Deleuze, 1993 $3^{[1]}$

\section{The Undesigned Space}

The Western District Public Cargo Working Area (WDPCWA) in Hong Kong is never planned or designed as a formal open space ${ }^{(1)}$. Nonetheless, it is appropriated by people as a public space. The Public Space Awards 2013 in Hong Kong has triumphed the place with its degree of freedom and flexibility. Despite accessing the area for purposes other than logistic functions is technically unauthorized, the space, with its spectacular waterfront view, has received breadth of media coverage and attracted regular crowd of people.

Institutional maps have portrayed the place as a plain and empty surface without representing the diverse human activities and interactions intertwined with political, economic, social and environmental nexuses that the space characterizes. The natural occurrence of vibrant activities within the WDPCWA is in opposite to the practice and pedagogy of urban planning and design.

Conventional design approaches focusing on tangible, well defined, quantitative, geometric and geographic terms fail to frame these undesigned activities and the perception which are intangible, boundless and in flux.

Public use in the WDPCWA is tactical in nature, exploring legal loopholes and spatial and temporal possibilities, then utilizes, negotiates, and appropriates it. The space represents a different aesthetic appreciation, a different perception towards urban space
(1) According to The Hong Kong Planning Standards and Guidelines (HKPSG) promulgated by the Planning Department "Open Space" is a statutory land use zone for the provision of open space and recreation facilities for the enjoyment of the general public. It is the statutory reference of all public space in Hong Kong.
5. 因为没有任何一个组织 具有为这片区域制定规 则的合法权力，每个 则的合法权为, 每个 组织都在试探对方的底 线, 或仅仅做到满足 施压者不断变化的预 期。

6. 在这里, 各种活动相巨 制约。比如, 货运商如 何存放这些运货板与很 多其他因素 (如当地的 需求量）互有影响。

5. Since no parties are legitimate to rule the use of the space, each party is in a mode of testing the bottom line or simply do their job to fulfill the changing expectations of their source of pressure. source of pressurities are

mutually regulating. For example, how operators store the pallets matters and in turn influenced by all sorts of attributes including local demand.

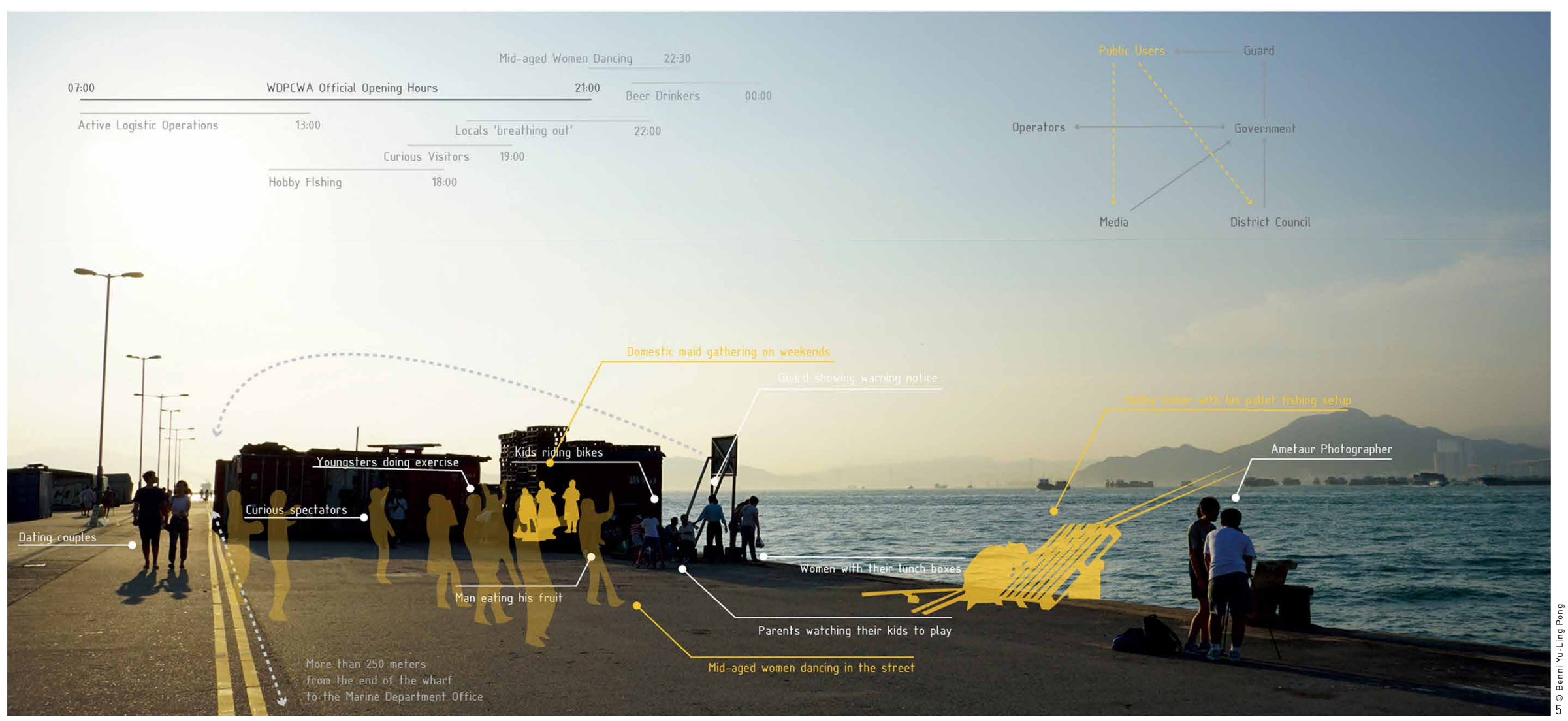




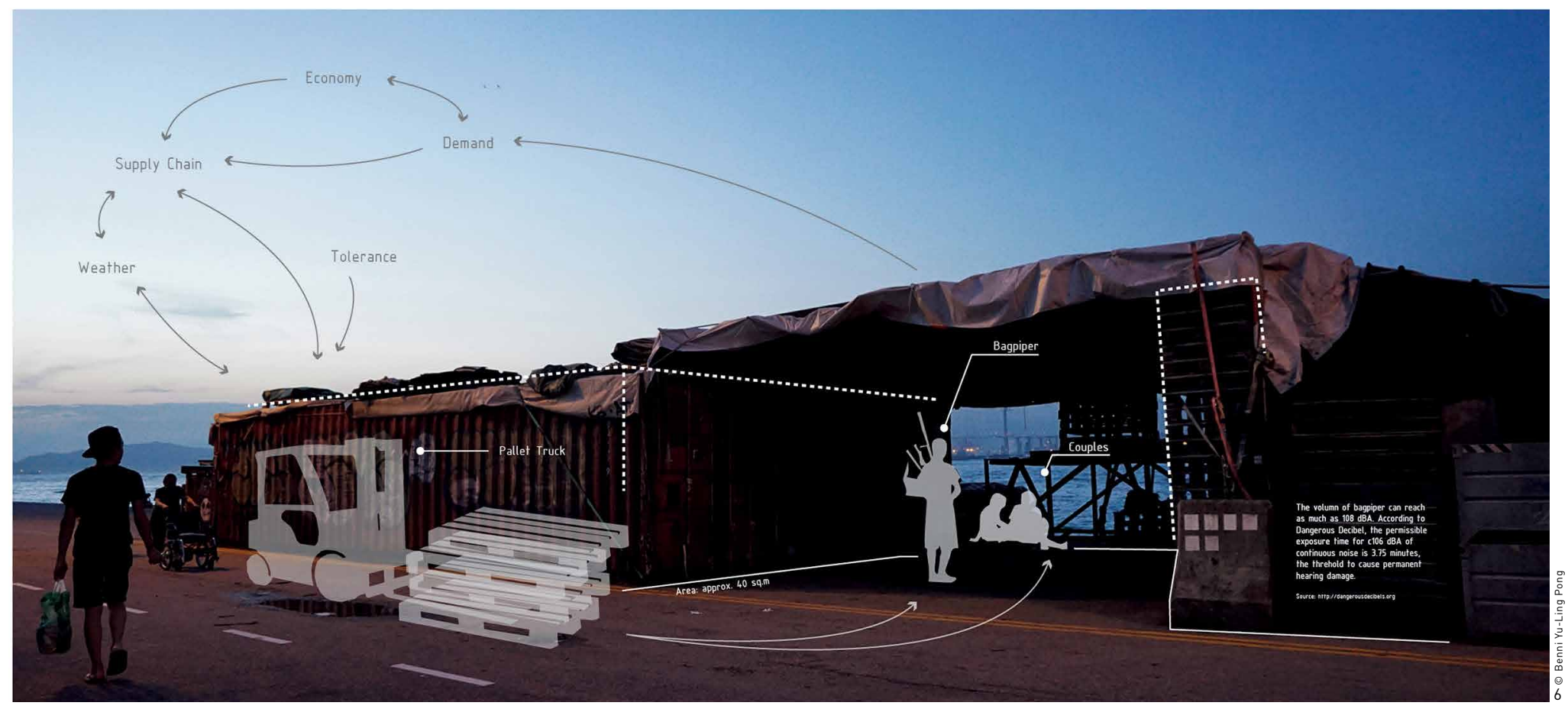

and a different understanding of urbanism. This project intended to conceptualize and unravel the veiled folds embedded in the space and nuances which were often overlooked and obscured in design practice, and scrutinized the perceptually defined aesthetic value in undesigned space.

\section{Design Anthropology}

Anthropological enquiry of space often overlaps with the interests of urbanists. Mechanical site analysis in design process seldom incorporates extensive field observation. This project combined ethnographic method and visual representation. It argued that if designers had exposed sufficiently long enough time with in-depth investigations towards a space and the community, design practice might behave differently.

Ethnographers commonly struggle from being an objective observer and often have to mentally prepare for uneasy time particularly when target groups are marginally positioned in the society. It was generally not the case in my initial study. The practice of participatory observation might have much more fun than reading the methodology literature. Unexpected surprises and opportunities to interact with people happened only by chance and by verbal network. Simply sitting and talking at the pier appeared to be the best strategy.

\section{Appropriated Space and the Sky Mirror}

The WDPCWA, commonly known as Sai Wan Pier or Instagram Pier, was located at the Western District in Hong Kong and was a reclamation land exclusively planned for pier and public cargo handling works only. Local residents occasionally appropriated the space since it was constructed. The space was only unveiled to the larger public when being elected as the most popular public space and after myriad of images being shared in Instagram and lately appeared in TIME magazine and National Geographic. Regardless of its romantic nickname, the "Sky Mirror of Hong Kong" referred to the unmaintained surface located at the tip of the main wharf. The sunken surface was so extensive that after rainy days, it formed a slice of thin water on top, perfectly mirroring the panoramic view of the Victoria Harbour and the exquisite sunset.

For local residents, the space was part of their neighborhood. Many would insist that the pier they saw was different from the "outsiders." Some did believe that they had the "right" and "responsibility" to insert moral rules and orders to the space, at least verbally. To the non-locals, visiting the WDPCWA was by no means part of their life. They came to discover the "hidden paradise." The more you warned them, the more they desired to visit. There were also users of marginality that their activities were so subtle as if they were invisible.

These users had very different preference towards the use of space. Regardless of their perceptions, the unprogrammed plain platform in the 


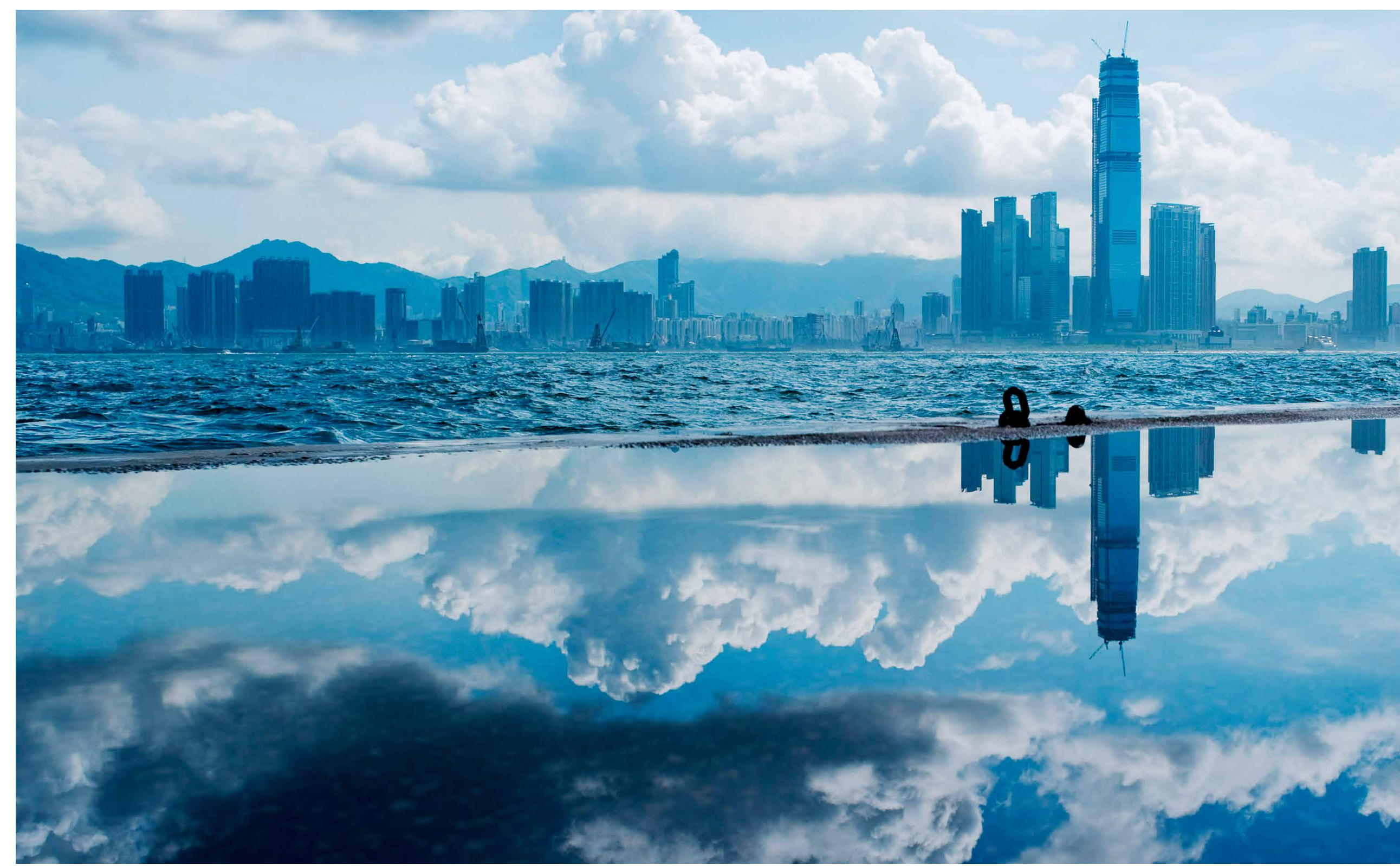

WDPCWA appeared to have induced

maximum diversity of human activities and imaginations.

\section{Tacit Agreement}

The vibrant activities in the pier often created an illusion that the space was "rule-less." In fact, the WDPCWA had many rules. A warning sign by Marine Department was unmistakably posted at the entrance and the cargo operators also scattered informal warning signs with slang languages in their berth area. Entering the site during operation hours, facing the "aggressive" eyes from tattooed and half-naked male workers might not be a pleasant experience. This was polemical particularly because the WDPCWA was a harmonious family gathering space during the non-operation hours.

The cargo operators generally had reasonable tolerance towards public use. Since the government had a plan to alter the land use from logistic functions to waterfront promenade, they realized that embracing public use could be beneficial to them. They once urged for a win-win proposal to balance public enjoyment and logistic functions. The public users were well aware that if their activities raised the concerns of the Marine Department or the cargo operators, they might risk being 


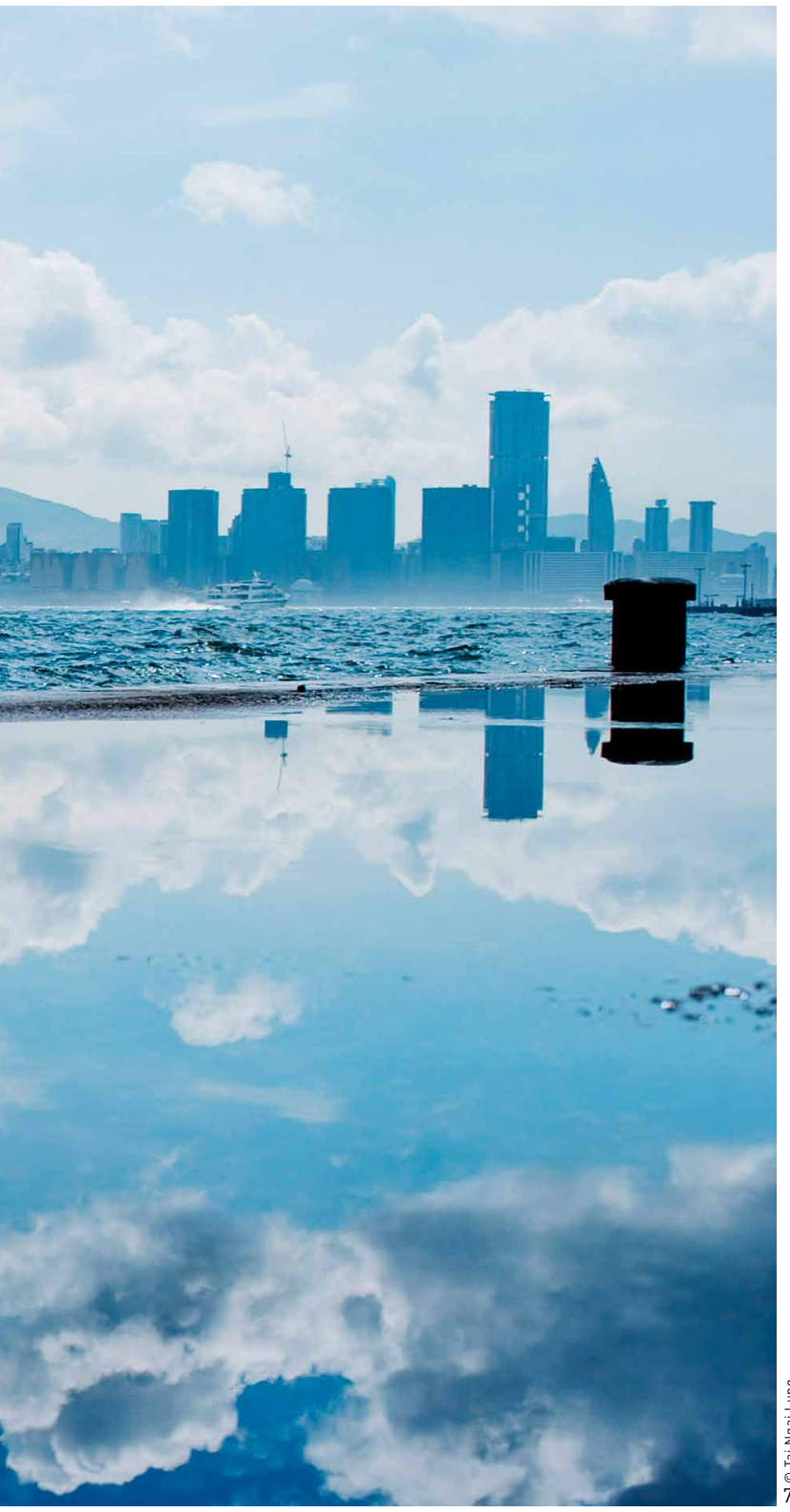

7. “香港天空之镜”

8. “香港天空之镜”上的 活动方式表现了公众 使用和监管制度之间 的博弯。

7. The "Sky Mirro Image

8. Activities in the Sky Mirror of Hong Kong imply tactic and struggle between public use and institutional control prohibited to use the space. It was clear that they had skillfully captured the idle space and hours without disturbing the logistic operations. In response to occasional complaints, the Marine Department had emphasized the need to keep the public off for safety reasons. The guards would sometimes hand the warning notice to the public, advising people to leave. However the actions of the people were not affected partly because the attitude of the guards simply did not suggest any urgency nor people believed that they would be punished.

The relationship between users, government, and operators were built upon the "trouble avoidance" mentality. The tacit agreement stated: "as long as there was no big trouble, things could go on." Activities among users were mutually regulating. But not having any written regulations did not mean that there was no order. The unspoken rules based on social norms among the strangers had governed human behaviors.

\section{Symbolization: The Past and the Future}

Many interviewees could accurately describe the history of the district and the locations of demolished landmarks. The "untrammeled" pier was a symbol to many local residents with a sense of "recalling the good old days" in Hong Kong. More than the past, the WDPCWA also gives people a sense of hope in the future. Green Peace used the pier as the background to promote their campaign. Even the government advertisement celebrating the 20th anniversary of the establishment of the Hong Kong Special Administrative Region filmed at the site. In the scene showing the WDPCWA, the subtitle of the advertisement wrote: "This is where we see our future and live our dream." The openness of the site seemed to have casted away the uncertainties shadowing the future of the WDPCWA. Many interviewees projected the ideal Hong Kong in their minds and considered the space as a living example to demonstrate the possibility of alternative mode of development.

The WDPCWA was meant to be ephemeral. One institutional design proposal had literally referred the current pier as "chaotic and boring." The plan recommended to transform the pier into the "Western Gateway of Hong Kong." The current human activities were entirely ignored. The plan was not totally topdowned. It was built upon an initiative from a local NGO and had referenced other bottom-up planning models in neighboring

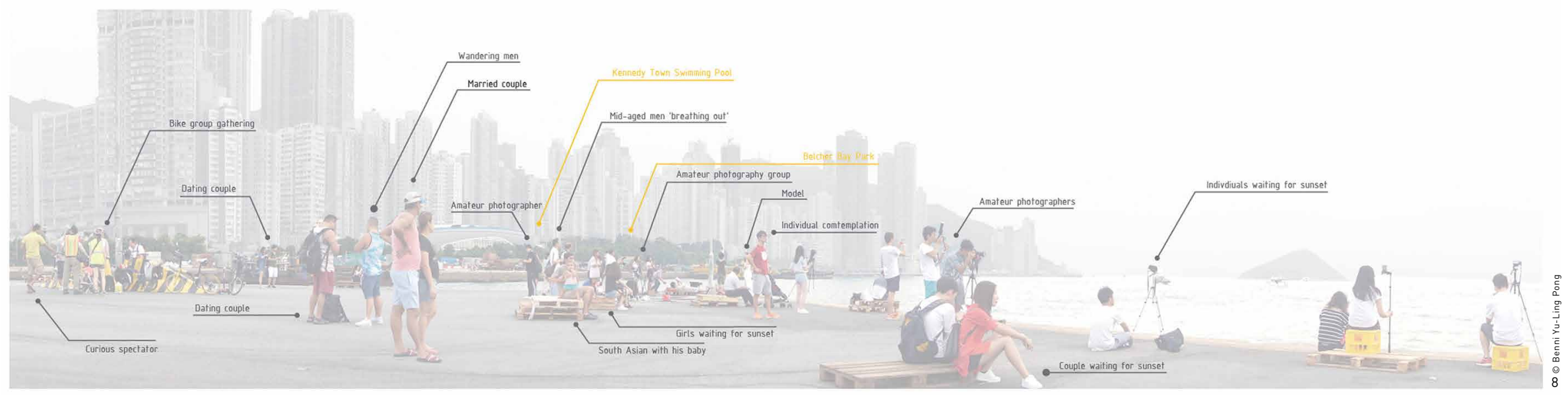


districts. In any case, the existing pier users would not have any substantial influence to the future of the WDPCWA either because they were reluctant to participate in the formal planning process or the expected "benefits" of the new plan could easily outweigh the arguments of maintaining the status quo.

\section{The Other Aesthetics}

Not everyone would glorify the WDPCWA. There were many people who might prefer using the designed parks. Some people perceived the pier as a "dangerous" place. It was this perception that limited the "over-use" of the space and kept the WDPCWA off from the radar. Walking into this hidden space is a form of flâneur, and a safe adventure to discover an exotic part of the city. It was a place to do something slightly insane. It was a place where inaccessible things became accessible. It evoked our childhood memory and a sense of playfulness.

Ignasi de Sola-Morales Rubio used the term "Terrain Vague" to describe the post-industrial derelict urban landscape ${ }^{[2]}$ The definition of terrain vague - "Vague: empty, unoccupied," yet also "free, available, unengaged" matched the quality of the WDPCWA. Christophe Girot argued that "Terrain Vague" was a prevailing phenomenon in the 20th century territory and a "complete antithesis of conscious landscape design." ${ }^{[3]}$

How could we incorporate this unusual aesthetic value into our design practice became an interesting question.

\section{Designers on “Undesigned" Space}

Design is a systematic process. It promises the provision of innumerable quantitative data and claims to have reflected the interconnected relationship the mainstream design and planning canons concern. But these data do not measure the aesthetic value, personal experience, perception, or sense of freedom people enchanted in the WDPCWA. With the same methodology in design where certain qualitative information is rendered invisible, the outcome will always be similar.

Designing nothing is a bold action. The urge for more programme is desperate. Not only clients request for higher economic returns, designers parallel the quantitative index and form to successful designs. Designers are trapped in between being perfectionists and pragmatists but often overlook the need of the real users.

I have discussed the WDPCWA with many of my peers. While most of them are captivated by the space, their comments and critiques all point to the same concern - what can designers learn from the space? Many may expect that panacea could be extracted through the investigation of the pier and formulate design typologies that create a "successful" space. On the other hand, advocacy groups frequently accuse designers of ruining public space. To blame all these things solely on design is as naive as thinking that good designs could resolve everything. Public space is fascinating exactly because of its indeterminacy, interactions and complexity.
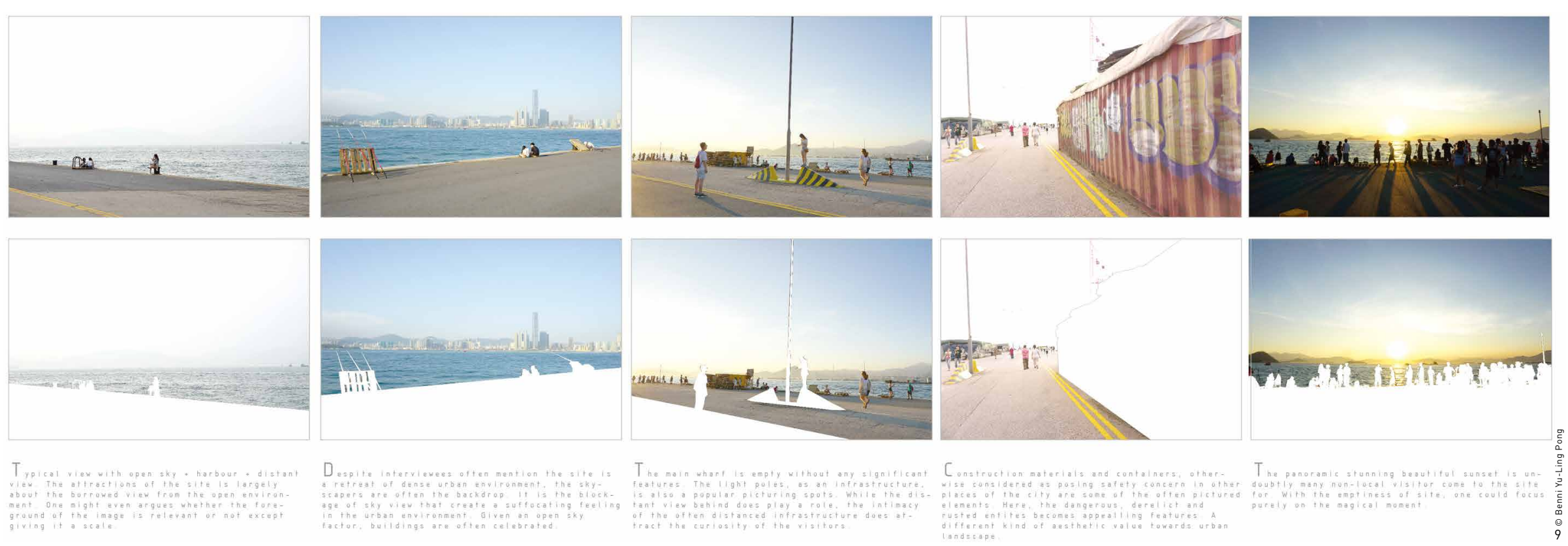
I NSTAGRAM ANALYS IS

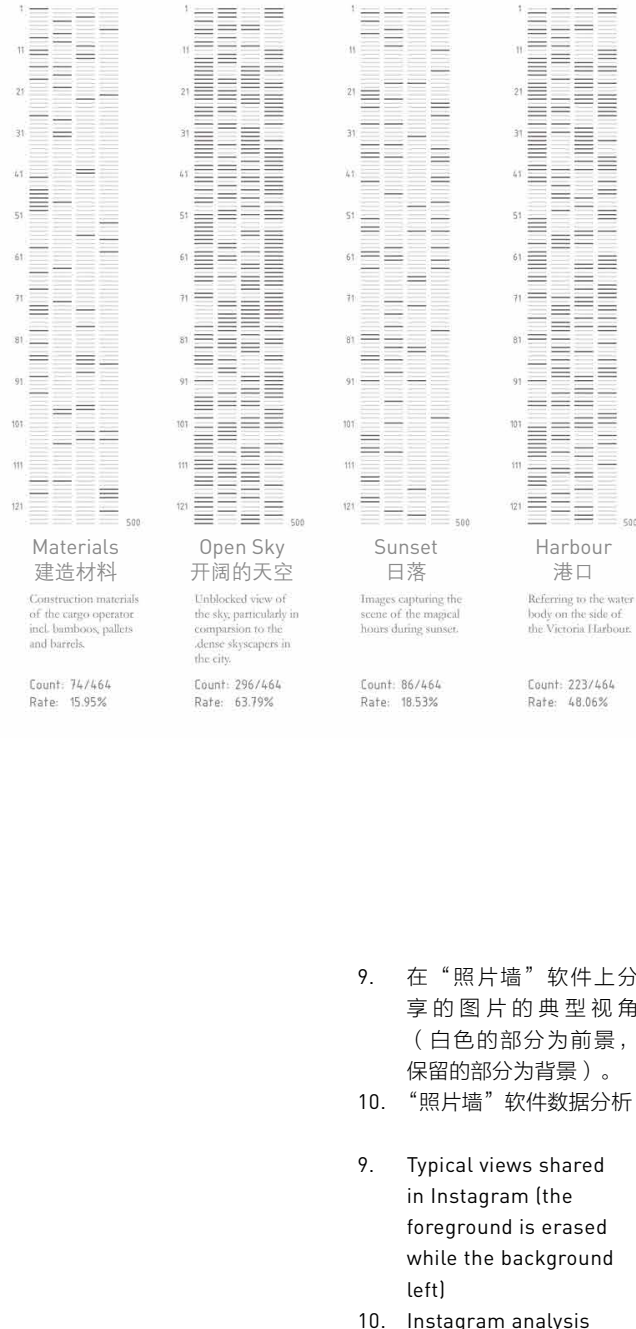

10. Instagram analysis
Anthropology is a potential methodology to connect design practice to the life and perception of human beings that are difficult to quantify. Design cannot be simply satisfied with "know-how" but has to "know-why" as well. If design is a catalyst to social change, it has to be conscious to what it may change. This project started with the objective to resolve some problems in the design process, and ended with unfolding more questions in the mainstream pedagogy. When people ask about my vision towards the future of the pier, I guess I simply do not know. Instead of thinking a solution could be offered, I tend to deem my study as the start of a continuous process, exploring how design could interact with human perception and the community. LAF

\section{REFERENCES}

[1] Deleuze, G., \& Conley, T. (Tran.). (1993). The Fold: Leibniz and the Baroque (p. 86). Minneapolis: University of Minnesota Press.

[2] Rubio, I. de S. M. (1995). Terrain Vague. In C. C. Davidson (Ed.), Anyplace, 118-123.

[3] Girot, C. (2016). The Course of Landscape Architecture: A History of our Designs on the Natural World, from Prehistory to the Present (p. 283). London: Thames \& Hudson. 